\title{
Keabsahan Akta Akad Murabahah Berdasarkan Kepatuhan Syariah (Studi Kasus terhadap Putusan Nomor 1957/Pdt.G/2018/PA.Js)
}

\author{
Surya Mustika Rajamuddin Putra \\ Magister Hukum Fakultas Hukum Universitas Islam Indonesia Yogyakarta Indonesia \\ Jln. Cik Di Tiro No. 1 Yogyakarta Indonesia \\ suryamustikarj@yahoo.com
}

\begin{abstract}
The problems raised in this article are first, to examine the opinion of the judge in the decision Number 1957/Pdt.G/2018/PA.Js. Second and the implications of this decision. This is a normative legal research which is analyzed by using a qualitative descriptive method. The results of this study concluded that the judge used Article 22 of the KHES to examine the cases of the parties in the verdict No. 1957/Pdt.G/2018/PA.Js. The implication of the decision is that the judge declared the murabahah contract of the parties null and void because it was not in line with sharia compliance as stated in the legislation.
\end{abstract}

Key Words: Akad validity; notary deed; sharia compliance

\begin{abstract}
Abstrak
Permasalahan yang diangkat dalam artikel ini yaitu, pertama, mengkaji pendapat hakim dalam putusan Nomor 1957/Pdt.G/2018/PA.Js. Kedua, implikasi dari adanya putusan tersebut. Adapun penelitian ini adalah penelitian hukum normatif yang dianalisis menggunakan metode deskriptif kualitatif. Hasil penelitian ini menyimpulkan bahwa hakim menggunakan Pasal 22 KHES untuk memeriksa perkara para pihak dalam putusan putusan Nomor 1957/Pdt.G/2018/PA.Js. Implikasi putusan tersebut ialah hakim menyatakan akad murabahah para pihak batal demi hukum karena tidak sejalan dengan kepatuhan syariah sebagaimana tertuang dalam peraturan perundang-undangan.
\end{abstract}

Kata-kata Kunci: Keabsahan akad; kepatuhan syariah; akta notaris 


\section{Pendahuluan}

Demi menghindarkan bank syariah dari pelanggaran hukum, lembaga tersebut harus tunduk pada kepatuhan syariah (sharia compliance). Hal ini penting mengingat ketidakpatuhan bank syariah terhadap sharia compliance akan berakibat pada dihentikannya operasionalisasi bank tersebut. ${ }^{1}$ Kepatuhan syariah tidak hanya menuntut bank syariah untuk patuh dalam hal kelembagaan, melainkan juga kegiatan usahanya serta cara dan proses dalam melaksanakan kegiatan usaha tersebut. Ini sebagaimana yang diperintahkan oleh Undang-Undang No. 21 Tahun 2008 tentang Perbankan Syariah selanjutnya disebut UU No.21/2008.

Pembiayaan bank syariah kepada nasabah sebagai kegiatan usaha bank syariah merupakan hubungan hukum yang harus dituangkan secara tertulis di dalam akad. ${ }^{2}$ Substansi dari akad tersebut memuat hak dan kewajiban pihakpihak yang tidak boleh bertentangan dengan prinsip syariah. ${ }^{3}$ Berkaitan dengan hal tersebut, apabila pihak-pihak menghendaki akadnya dalam bentuk akta notaris, maka notaris perlu memperhatikan secara saksama agar substansi akta yang akan dibuat tidak menyimpang dari syariat Islam.

Perlu diketahui bahwa notaris merupakan jabatan profesi penunjang kegiatan usaha perbankan syariah, dimana notaris berwenang meresmikan akta autentik demi menjaga kepastian hukum. Oleh karena itu, dalam pelaksanaan tugas tersebut notaris dituntut pula untuk memiliki kepatuhan syariah. Jika tidak, maka notaris dianggap tidak efektif sebagai jabatan profesi penunjang perbankan syariah dan justru menimbulka risiko kerugian bagi para pihak yang bertransaksi. ${ }^{4}$

Perjanjian yang berisi transaksi, baik dalam bentuk akta autentik maupun dalam bentuk dibawah tangan, dianggap sah jika memenuhi syarat Pasal 1320 KUH Perdata. ${ }^{5}$ Jika perjanjian itu mengenai transaksi perbankan syariah, maka Pasal 1320 KUH Perdata saja belum cukup, melainkan harus pula mengikuti syarat lain yang ditentukan hukum Islam yakni memenuhi rukun dan syaratnya ${ }^{6}$ serta tidak mengandung unsur riba, maisir, gharar, haram, dan zalim sebagaimana yang diatur dalam UU No.21/2008.

${ }^{1}$ Agus Triyanta, Hukum Perbankan Syariah, Setara Press, Malang, 2016, hlm. 70.

2 Pasal 1 Angka 13 UU No.21/2008.

${ }^{3}$ Habib Adjie \& Muhammad Hafidh, Akta Notaris Untuk Perbankan Syariah, PT. Citra Aditya Bakti, Bandung, 2017, hlm. 55.

4 Ro'fah Setyowati, “Notaris Dalam Sengketa Perbankan Syariah”, Jurnal Masalab-Masalah Hukum, Jilid 45 No. 2, 2016, hlm. 135.

5 Keabsahan Perjanjian yang Dibuat di Bawah Ancaman, https://www.hukumonline.com/klinik/detail/ ulasan/lt516f36437d214/keabsahan-perjanjian-yang-dibuat-di-bawah- ancaman/, diakses pada 24 September 2020, pukul 16.24 WIB.

${ }^{6}$ Lihat Pasal 22 Peraturan Mahkamah Agung No. 2 Tahun 2008 tentang Kompilasi Hukum Ekonomi Syari'ah. 
Akta autentik yang dibuat oleh notaris merupakan akta yang terjamin kepastian hukumnya dan berkekuatan hukum sempurna sebagai alat bukti. Dengan adanya unsur pejabat dalam akta autentik menyebabkan akta tersebut sulit ditemukan celah ataupun cacat hukumnya. Akan tetapi pernyataan tersebut tidak serta merta membuat akta notaris terbebas dari masalah hukum, bahkan akta notaris dapat berujung pada pembatalan oleh pengadilan. ${ }^{7}$ Sebagai contoh, terdapat sengketa ekonomi syariah yang telah diputus oleh Pengadilan Agama Jakarta Selatan melalui Putusan Nomor 1957/Pdt.G/2018/PA.Js mengenai keabsahan suatu akad pembiayaan murabahah beserta perjanjian tambahannya, yang mana terdapat dugaan pelanggaran kepatuhan syariah oleh bank syariah.

\section{Rumusan Masalah}

Berdasarkan latar belakang di atas, penelitian ini mengangkat dua rumusan masalah yaitu, pertama, apakah dasar pertimbangan hakim dalam memeriksa perkara para pihak dalam putusan Nomor 1957/Pdt.G/2018/PA.Js? Kedua, apa dasar pertimbangan hakim dalam memutus perkara sengketa ekonomi syariah pada Pengadilan Agama Jakarta Selatan Nomor 1957/Pdt.G/2018/PA.Js?

\section{Tujuan Penelitian}

Adapun tujuan dari penelitian ini, pertama, untuk mengkaji keabsahan akad syariah dalam bentuk akta notaris yang tidak mengikuti kepatuhan syariah. Kedua, menganalisis dasar pertimbangan hakim dalam memutus perkara sengketa ekonomi syariah pada Pengadilan Agama Jakarta Selatan Nomor 1957/Pdt.G/2018/PA.Js.

\section{Metode Penelitian}

Metode yang digunakan adalah yuridis normatif, dimana menganalisis data dan norma-norma yang terdapat dalam peraturan perundang-undangan serta putusan pengadilan yang berkaitan dengan permasalahan. Pendekatan penelitian yang digunakan gunakan diantaranya pendekatan perundang-undangan (statue approach) dan pendekatan kasus (case approach). Penelitian ini menggunakan data sekunder yaitu data yang berasal dari data-data yang sudah tersedia misalnya, dokumen resmi, buku-buku atau surat perjanjian. Data sekunder dapat berupa bahan hukum primer, bahan hukum sekunder, dan bahan hukum tersier. ${ }^{8}$

\footnotetext{
7 Dedy Pramono, "Kekuatan Pembuktian Akta Yang Dibuat Oleh Notaris Selaku Pejabat Umum Menurut Hukum Acara Perdata di Indonesia”, Lex Jurnalica Vol. 12 No. 3, 2015, hlm. 256-257

8 Setiono, Pemahaman Terbadap Metode Penelitian Hukum (Diktad), Program Studi Ilmu Hukum Pascasarjana UNS, Surakarta, 2002, hlm 6. Dikutip oleh Kurniawan Andy Nugroho, “Analisis Putusan Hakim Pengadilan Negeri Dalam Perkara Tindak Pidana Penyimpanan Bahan Bakar Minyak Tanpa Izin Usaha Penyimpanan", Program Pascasarjana Universitas Sebelas Maret, Surakarta, 2014, Tesis, hlm. 53
} 


\section{Hasil Penelitian dan Pembahasan}

\section{Pertimbangan Hakim dalam Putusan Nomor 1957/Pdt.G/2018/PA.Js.}

Dalam perkara ini, Penggugat mempersoalkan keabsahan Akta Akad Pembiayaan Investasi Pengalihan Pembiayaan Dengan Menggunakan Prinsip "Murabahah" Nomor. -, tertanggal, 31 Juli 2013, yang dibuat di hadapan Tergugat II (Notaris). Berkaitan dengan dalil-dali Penggugat, Tergugat I pada pokoknya menolak gugatan penggugat dan menyatakan telah melakukan prosedur yang benar dalam mematuhi aturan hukum dan prinsip-prinsip tentang murabahah. Begitu pula dengan Tergugat II yang pada pokoknya menolak gugatan Penggugat Konvensi dan menyatakan bahwa Tergugat II telah melakukan Jabatannya sebagai Notaris dengan menerbitkan Akta Notaris.

Setelah terungkap fakta-fakta formil dan materil, konsideran 27 membahas ketentuan Pasal 1338 jo. Pasal 1365 KUHPerdata, karena terkait dengan faktafakta formil tersebut di atas Pasal 1338 KUHPerdata menyatakan: "semua persetujuan yang dibuat secara sah, berlaku sebagai undang- undang bagi mereka yang membuatnya", Pasal 1365 KUH Perdata: "tiap perbuatan melawan hukum yang membawa kerugian kepada orang lain, mewajibkan seorang yang karena salahnya menerbitkan kerugian untuk mengganti kerugian tersebut".

Konsideran 33 majelis hakim memberikan pendapat hukum, bahwa akad menempati kedudukan sentral dalam lalu lintas ekonomi antara manusia (muamalah). Akad menjadi kunci lahirnya hak dan kewajiban (prestasi) yang lahir sebagai akibat hubungan kontraktual. Salah satu persoalan penting dalam akad adalah unsur-unsur yang harus terpenuhi sehingga akad secara hukum dianggap sah. Untuk sahnya suatu akad harus memenuhi rukun yang merupakan esensi dalam setiap akad. Pasal 22 KHES menyebutkan rukun akad ada 4 yaitu: pihak-pihak yang berakad, (2) obyek akad, (3) tujuan pokok akad, (4) kesepakatan. Para ahli hukum Islam telah sepakat bahwa obyek akad harus memenuhi empat unsur, yaitu: (1) obyek harus sudah ada ketika akad dibuat, (2) Barang yang menjadi obyek akad adalah barang yang dibolehkan oleh Syara', (3) obyek harus dapat diserahkan, (4) akad harus jelas diketahui oleh kedua belah pihak.

Berdasarkan hal tersebut majelis hakim secara nyata menggunakan Pasal 22 KHES sebagai dasar pertimbangannya untuk menguji keabsahan akta akad murabahah, kemudian menggunakan Pasal 1338 jo Pasal 1365 KUHPerdata. Tentu pasal tersebut tidak serta merta langsung begitu saja berlaku, karena keberlakuan pasal tersebut harus didukung dengan adanya bukti formil dan materiil yang relevan yang dihadirkan di dalam persidangan. Sehingga akta akad 
yang menggunakan prinsip murabahah dan perjanjian ikutannya yang dipersoalkan Penggugat terbukti tidak sah dan dinyatakan batal oleh majelis hakim karena Tergugat I (Bank Syariah) dan Tergugat II (Notaris) melakukan perbuatan melawan hukum mengenai merubah akta akad murabahah tersebut secara sepihak tanpa persetujuan Penggugat. Hal ini sejalan dengan Ketentuan Ketiga Fatwa DSN MUI No.111/DSN-MUI/IX/2017 tentang Akad Jual Beli Murabahah mengenai Sigat al-Aqd yang menyatakan: ${ }^{9}$

1. Akad jual beli murabahah harus dinyatakan secara tegas dan jelas serta dipahami dan dimengerti oleh penjual dan pembeli.

2. Akad jual beli murabahah boleh dilakukan secara lisan, tertulis, isyarat, dan perbuatan/tindakan, serta dapat dilakukan secara elektronik sesuai syariah dan peraturan perundang-undangan yang berlaku.

3. Dalam hal perjanjian jual beli murabahah dilakukan secara tertulis, dalam akta perjanjian harus terdapat informasi mengenai harga perolehan $\left(\mathrm{ra}^{\prime} \mathrm{s}\right.$ mal al-murabahah), keuntungan (al-ribh), dan harga jual (tsaman almurabahah).

Dapat dipahami bahwa keberadaan "Akta Akad Murabahah" yang terdapat dalam perkara ini dinyatakan tidak sah karena terdapat bukti mengenai perubahan akta tersebut, tidak mematuhi ketentuan Sigat al-Aqd huruf a tersebut di atas. Hal ini karena akta tersebut dirubah secara sepihak oleh Tergugat I, kemudian menghasilkan "Akta Akad Murabahah" (fakta persidangan) yang substansinya tidak diketahui secara tegas dan tidak jelas serta tidak dipahami dan tidak dimengerti oleh Penggugat.

Terbukti bahwa bank syariah sebagai Tergugat I yang telah melakukan perbuatan melawan hukum, yang dengan sengaja mengubah suatu akad murabahah secara sepihak tanpa sepengetahuan atau disetujui oleh Penggugat maka dapat disimpulkan Tergugat I sebagai bank syariah tersebut telah melakukan perbuatan zalim terhadap pihak Penggugat (melanggar kepatuhan syariah) dimana perubahan akad itu menimbulkan kerugian kepada Penggugat. Sehingga langgaran kepatuhan syariah oleh bank syariah, berimplikasi kepada akadnya yang dinyatakan tidak sah dan dinyatakan batal.

\section{Implikasi Putusan Nomor 1957/Pdt.G/2018/PA.Js.}

Melihat perkara No.1957/Pdt.G/2018/PA.Js, bahwa akta akad yang menggunakan prinsip murabahah, dimana akta tersebut terbukti cacat hukum di persidangan karena tidak terpenuhi rukun dan syarat akad sebagaimana yang diatur di dalam Pasal 22 KHES. Cacatnya suatu akad syariah ditentukan oleh

${ }^{9}$ Lihat Fatwa Dewan Syariah Nasional Majelis Ulama Indonesia No.111/DSN-MUI/IX/2017 tentang Akad Jual Beli Murabahah 
persepktif Islam dan perspektif positif. Pada perspektif figh, cacatnya suatu akad disebabkan oleh empat hal yakni: 1) Paksaan, 2) Khilaf, 3) Penipuan, dan 4) Tipu Muslihat. Sedangkan di dalam perspektif positif cacatnya suatu akad diakibatkan karena: 1) Paksaan, 2) Khilaf (kekeliruan), 3) Penipuan, dan 4) Penyalahgunaan Keadaan, penyalahgunaan tersebut dalam perspektif Islam dapat disamakan dengan tipu muslihat atau al-Ghubnu (tipuan), di dalam Undang-Undang penyalahgunaan keadaan belum tercantumkan akan tetapi telah menjadi yurispudensi di Indonesia yang telah banyak digunakan oleh hakim dalam memutuskan perkara. ${ }^{10}$

Cacat hukum suatu akad syariah dalam perkara No.1957/Pdt.G/2018/PA.Js yang menyatakan akad tidak sah, sangat jelas akad tersebut melanggar baik persepktif Islam maupun hukum positif. Bank syariah sebagai pihak yang melakukan perbuatan melawan hukum ditafsirkan pula melanggar kepatuhan syariah. Jika kepatuhan syariah (sharia compliance) merupakan ketaatan bank syariah terhadap prinsip-prinsip syariah ${ }^{11}$, maka implementasi kegiatan usaha bank syariah di lapangan, seharusnya tidak boleh menyimpang dari syariat Islam. Secara tegas dalam hukum UU No. 21/2008 tentang Perbankan Syariah, yang dimaksud melanggar syariat Islam adalah kegiatan perbankan syariah yang mengandung unsur gharar, riba, maisir, haram, atau zalim. Jika kegiatan itu tetap berjalan, maka seketika berdampak langsung kepada akad yang lahir dengan substansi yang melanggar syariat Islam.

Syarat sahnya akad syariah sudah ditetapkan di dalam peraturan perundang-undangan. Secara runtut dimulai dari Peraturan Mahkamah Agung No. 2 Tahun 2008 tentang Kompilasi Hukum Ekonomi Syariah (KHES), Pasal 22 (sahnya suatu akad) jo Pasal 26 (larangan terhadap akad). Oleh karena Pasal 26 mencantumkan syariat Islam, maka akad tidak boleh bertentangan dengan hukum Islam (termasuk Fatwa Dewan Syariah Nasional yang ketentuanketentuannya berisi tentang dalil-dalil hukum Islam). Kemudian UndangUndang No. 21 Tahun 2008 tentang Perbankan Syariah, Pasal 2 di dalam penjelasannya bahwa bank syariah dalam menjalankan kegiatan usahanya tidak boleh ada unsur riba, maisir, gharar, haram, dan zalim. Hal ini cukup jelas bahwa bank syariah/unit usaha syariah dituntut untuk taat kepada hukum Islam dalam menjalankan kegiatan usaha perbankan, sehingga setiap akad antara bank syariah/unit usaha syariah dan nasabah dalam rangka penyaluran dana kepada nasabah, harus sesuai dengan Pasal 2 UU No. 21/2008.

10 Ahmad Danu Syaputra, "Cederanya Akad/Perjanjian Dalam Perspektif Fiqih dan Hukum Positif”, Jurnal Syariah, Vol. V, No. 1, 2017, hlm. 120.

${ }_{11}$ Muhammad Syafei Antonio, Bank Shariah bagi Banker dan Praktisi Kenangan, Tazkia Institute, Jakarta, 2001, hlm. 12 
Konsekuensi hukum atau akibat hukum oleh akad jika melanggar KHES Jo. UU No. 21/2008 Jo. Peraturan Perundang-Undangan terkait Jo. Hukum Islam, maka dapat berlaku Pasal 27 KHES, bahwa akad berstatus hukum menjadi akad yang fasad (akad yang dapat dibatalkan) atau akad yang batal (akad yang batal demi hukum). Hal ini dibuktikan pada perkara No. 1957/Pdt.G/2018/PA.Js, dimana perbuatan melawan hukum bank syariah sebagai bentuk ketidakpatuhan terhadap syariat Islam (bertindak zalim), maka berimplikasi langsung kepada status hukum akta akad murabahah (perjanjian pokok) menjadi akad yang fasad, dan berimplikasi pula kepada seluruh akta lainnya sebagai perjanjian ikutan dari perjanjian pokok tersebut, sehingga akta-akta tersebut dinyatakan batal.

\section{Penutup}

Dari keseluruhan uraian tersebut di atas, dapat diambil kesimpulan, pertama, melihat realitas penegakan hukum dalam perkara ekonomi syariah di Pengadilan Agama Jakarta Selatan khususnya dalam perkara No. 1957/Pdt.G/2018/PA.Js, bahwa majelis hakim menggunakan Pasal 22 KHES dan Pasal 1365 KUHPerdata sebagai dasar pertimbangan untuk menentukan keabsahan akta murabahah para pihak. Implikasi dari pertimbangan dalam putusan tersebut ialah hakim menyatakan Akta Akad Pembiayaan Investasi Pengalihan Pembiayaan No. -, tertanggal, 31 Juli 2013, yang dibuat di hadapan Notaris berkedudukan di Jakarta Utara, tidak sah dan batal demi hukum karena terbukti melanggar ketentuan-ketentuan di atas.

Berdasarkan kesimpulan tersebut, penulis menyampaikan rekomendasi yaitu, pertama kepatuhan syariah (sharia compliance) kepada bank syariah atau unit usaha syariah dalam menjalankan usahanya, seharusnya lebih diperkuat pada sektor pengawasannya. Selain bank syariah dan unit usaha syariah yang harus tunduk kepada kepatuhan syariah, Notaris sebagai pejabat yang meresmikan akta akta akad syariah dalam bentuk akta autentik, seharusnya memiliki kapasitas dan kapabilitas, serta memahami peraturan perundang-undangan terkait transaksi syariah dan hukum Islam, khususnya di bidang muamalah pada ekonomi syariah agar dengan mudah memahami maksud dan tujuan pihak-pihak yang menginginkan akad syariah untuk dituangkan ke dalam bentuk akta autentik. Dengan kata lain, Notaris harus tunduk pula kepada kepatuhan syariah. Kedua, Sudah semestinya Hakim dengan kewenangannya yang bebas untuk mengedepankan pemeriksaan bukti materil dan formil dalam sengketa ekonomi syariah. Dengan maksud hakim senantiasa berhati-hati agar tidak salah dalam menerapkan hukum dan mencapai suatu keputusan bagi pihak-pihak bersengketa yang berkeadilan. 


\section{Daftar Pustaka}

\section{Buku}

Adjie, Habib \& Muhammad Hafidh, Akta Notaris Untuk Perbankan Syariah, PT. Citra Aditya Bakti, Bandung, 2017.

Syafei Antonio, Muhammad, Bank Shari'ah bagi Banker dan Praktisi Keuangan, Tazkia Institute, Jakarta, 2001

Triyanta, Agus, Hukum Perbankan Syariah, Setara Press, Malang, 2016.

\section{Hasil Penelitian/Tugas Akhir}

Kurniawan Andy Nugroho, Analisis Putusan Hakim Pengadilan Negeri Dalam Perkara Tindak Pidana Penyimpanan Bahan Bakar Minyak Tanpa Izin Usaha Penyimpanan, Tesis, Program Pascasarjana Universitas Sebelas Maret, Surakarta, 2014.

\section{Jurnal}

Ro'fah Setyowati, “Notaris Dalam Sengketa Perbankan Syariah”, Jurnal MasalahMasalah Hukum, Jilid 45 No. 2, 2016.

Dedy Pramono, “Kekuatan Pembuktian Akta Yang Dibuat Oleh Notaris Selaku Pejabat Umum Menurut Hukum Acara Perdata di Indonesia", Lex Jurnalica Vol. 12 No. 3, 2015.

Ahmad Danu Syaputra, "Cederanya Akad/Perjanjian Dalam Perspektif Fiqih dan Hukum Positif", Jurnal Syariah, Vol. V, No. 1, 2017.

\section{Internet}

Keabsahan Perjanjian yang Dibuat di Bawah Ancaman, https://www.hukumonline.com/klinik/detail/ulasan/lt516f36437d214/ keabsahan-perjanjian-yang- dibuat-di-bawah-ancaman/, diakses pada 24 September 2020.

\section{Peraturan Perundang-Undangan}

Kitab Undang-Undang Hukum Perdata (Burgerlijk Wetboek)

Undang-Undang Nomor 2 Tahun 2014, Lembaran Negara Nomor 3; Tambahan

Lembaran Negara Nomor 5491, tentang Perubahan Atas UndangUndang Nomor 30 Tahun 2004 tentang Jabatan Notaris.

Undang-Undang Nomor 30 Tahun 2004, Lembaran Negara Nomor 117, Tambahan Lembaran

Negara Nomor 4432 tentang Jabatan Notaris.

Undang-Undang Nomor 21 Tahun 2008, Lembaran Negara Nomor 98, Tambahan Lembaran

Negara Nomor 4867 tentang Perbankan Syariah.

Peraturan Mahkamah Agung Republik Indonesia Nomor 2 Tahun 2008 tentang Kompilasi Hukum Ekonomi Syari'ah.

Peraturan Bank Indonesia Nomor: 13/2/PBI/2011 tentang Pelaksanaan Fungsi Kepatuhan BankUmum. 
Peraturan Bank Indonesia Nomor: 9/19/PBI/2007 tentang Pelaksanaan Prinsip Syariah Dalam Kegiatan Penghimpunan Dana dan Penyaluran Dana serta Pelayanan Jasa Bank Syariah.

Peraturan Bank Indonesia Nomor: 7/46/PBI/2005 tentang Akad Penghimpunan dan Penyaluran Dana Bagi Bank yang Melaksanakan Kegiatan Usaha Berdasarkan Prinsip Syariah.

\section{Putusan Pengadilan}

Putusan Pengadilan, pada Pengadilan Agama Jakarta Selatan, Nomor 1957/Pdt.G/2018/PA.Js.

Fatwa Dewan Syariah Nasional Majelis Ulama Indonesia

Fatwa Dewan Syari'ah Nasional Majelis Ulama Indonesia No. 111/DSNMUI/IX/2017 tentang Akad Jual Beli Murabahah. 